\title{
NO. 175
}

$\mathrm{MARCH}$

2021

\section{KEY POINTS}

- The devastating impact of the COVID-19 pandemic on the economies of Southeast Asia has increased the urgency for structural reform to support recovery and a return to sustainable, broadbased growth.

- Post-COVID-19 tourism will focus more on health and safety, attract tourists from nearby countries and domestically, and shift toward more environmentally sustainable practices.

- The agro-processing sector will move toward adding value and increasing productivity, improving its resilience, and upgrading supply chains.

- Targeting new markets, adopting new technologies, and shortening the supply chain can help support the recovery of the garments sector.

- The development of the electronics sector can be promoted through enhancing special economic zones and investing in human capital.

- Developing a digital trade sector will require a clear industry road map combined with the appropriate regulatory framework and strong connectivity.

\section{Supporting Post-COVID-19 Economic Recovery in Southeast Asia}

\section{INTRODUCTION}

The coronavirus disease (COVID-19) pandemic has had a devastating impact on the economies of Southeast Asia. Social distancing measures and border closures have decimated both domestic and external demand in consumer-driven sectors like retail, accommodation, and food services. The pandemic has increased the urgency and incentives for governments in the region to introduce structural reforms to support sustainable economic recovery.

After an analysis of different sectors, their potential for future growth, and the strengths of Southeast Asian countries, the Asian Development Bank (ADB) has identified five key sectors. Three are well-established sectors that need to be transformed or improved: tourism, agro-processing, and garments; and two are evolving sectors with high potential for future growth: electronics and digital trade. While our policy analysis focused on supporting the recovery and expansion of these sectors individually, crosscutting policies, such as support for an enabling business environment and improved infrastructure, will also be needed. Strengthening regional cooperation in Southeast Asia is important to help countries deal with future crises more effectively.

\section{TOURISM}

The tourism sector is an important driver of growth in gross domestic product (GDP) and employment in the region, but the COVID-19 pandemic has severely disrupted it, and it needs to adapt accordingly. Even prior to the pandemic, the industry was beset with four structural challenges: (i) an overreliance on foreign tourists from a limited number of countries focused on a few destinations, which led to reduced resilience and overcrowding; (ii) the lack of infrastructure outside major destinations, which limited the

This brief was based on research supported by the regional technical assistance on Policy Advice for COVID-19 Economic Recovery in Southeast Asia (TA 9964). It was jointly prepared by Bingxun Seng, Cheng Wei Swee, and Mohak Mangal from AlphaBeta; and Thiam Hee Ng and Dulce Zara from the ADB Southeast Asia Department (SERD) under the supervision of Alfredo Perdiguero, director, Regional Cooperation and Operations Coordination Division, SERD. Srinivasan Ancha, principal climate change specialist, Environment, Natural Resources and Agriculture Division, SERD; David Freedman, country economist, ADB Cambodia Resident Mission; Arndt Husar, senior public management specialist (digital transformation), Sustainable Development and Climate Change Department; and Steven Schipani, unit head, project administration, ADB Viet Nam Resident Mission provided invaluable comments.

Kevin Donahue provided editorial support.
ISBN 978-92-9262-752-2 (print) 978-92-9262-753-9 (electronic) ISSN 2071-7202 (print) ISSN 2218-2675 (electronic) Publication Stock No. BRF210101-2 DOI: http://dx.doi.org/10.22617/BRF210101-2 
potential for diversification; (iii) a significant share of low-wage and informal employment; and (iv) the amount of spending per tourist at levels below regional targets.

\section{Impact of COVID-19 on Tourism}

Apart from the unique attractiveness of the region's history, culture, and natural landscapes, low-cost air transport, rising incomes, and targeted tourism investment have led to rapidly growing tourism sectors in Southeast Asian countries. The number of visitor arrivals in the region increased significantly, from 37 million in 2005 to nearly 144 million in 2019 (ASEAN Statistics Division 2021). Pandemicrelated travel restrictions have devastated the tourism industry. Declines in foreign visitor arrivals in Southeast Asian countries in 2020 ranged from about $50 \%$ to $80 \%$, reaching nearly $100 \%$ in some popular destinations like Bali (Mufti and Akhlas 2020).

As the region recovers from the pandemic and looks forward to a resumption of sustainable and inclusive economic growth, there is likely to be greater focus on the following areas within the tourism sector.

Increasing emphasis on health and hygiene. The pandemic has made tourists much more aware of the importance of health precautions, making these considerations crucial in selecting travel destinations in the future. A World Economic Forum poll found that $72 \%$ of tourists would consider a destination's level of social responsibility in preventing the spread of COVID-19 before deciding to travel (Soni 2020).

Preference for proximity tourism. There have been indications that COVID-19 could lead to a fundamental decline in long-haul international tourism (i.e., a structural decline in total distance traveled per tourist per trip). Health and other concerns among travelers could lead to a shift in tourism patterns toward proximity tourism, or domestic and short-haul and international tourism (Romagosa 2020). A fall in household incomes due to the pandemic could make domestic tourism more economically attractive than traveling abroad. Finally, the adoption of digital tools to conduct virtual meetings could depress the demand for long-haul meetings, incentives, conferences and events tourism (OECD 2020).

Demand for environmentally sustainable tourism. COVID-19 is likely to lead to governments paying more attention to promoting higher-yielding environmentally sustainable tourism instead of mass tourism. While the rise of environmentally sustainable tourism is not a new trend, there is evidence that the pandemic has strengthened demand for it (Winterflood 2020).

\section{Post-COVID-19 Policy Response}

To maximize opportunities in the tourism sector in line with developments brought about by the pandemic, the governments in the region need to focus on the following areas (Figure 1):
Restoring demand. Countries will have to develop domestic marketing campaigns to convince travelers that it is safe to travel. This will require coordination and implementation of the proper procedures to reduce information gaps and minimize any risks. The rollout of vaccines will also help travelers feel safer.

Building new channels of demand. Countries should seek to diversify tourist destinations and develop lesser-known points of interest. Growing travel trends include ecotourism, which has the added benefit of helping to conserve natural areas. With increased focus on health and premium wellness experiences, there is potential for attracting more tourists in these areas. In addition, Muslim travelers are a fast-growing market. Having the necessary halal certifications and facilities will be crucial to attracting this clientele.

\section{Building capacities to support future digital demand.}

Authorities should invest in training tourism sector workers in both digital and non-digital skills to tackle the issues of low pay and informality. Higher-skilled workers will attract higher spending tourists, while new technologies can increase worker productivity in the tourism sector by $26 \%$ in the next 5 years (ADB a).

Increasing resilience. The tourism industry in each country will have to work closely with central and local governments to improve communication channels. The creation of a permanent crisis management task force can help ensure that a country's tourism sector is better able to cope with future shocks (Figure 1).

\section{AGRO-PROCESSING}

While agriculture has been declining as a share of GDP in Southeast Asia, it remains important as a major employer in many countries. The region has natural advantages in terms of the availability of arable land and workers, but there are challenges that were hindering growth in agro-processing even before the pandemic. Some of these are discussed below.

Inconsistent supply of raw materials. Factors affecting the supply of raw materials include adverse weather conditions, diseases, fluctuations in global market prices and exchange rates, limitations on cultivation of areas, and significant post-harvest food waste. Seasonality in raw material availability and lack of local smallholder farmer access to formal markets and businesses also prevent the efficient year-round operations of agro-processing companies (Deloitte 2019).

Low level of automation and technological adoption. The agroprocessing industry is largely labor-intensive in most Southeast Asian countries. Adopting more advanced and productive processing methods can help the agro-processing industry increase production volumes and add value. 


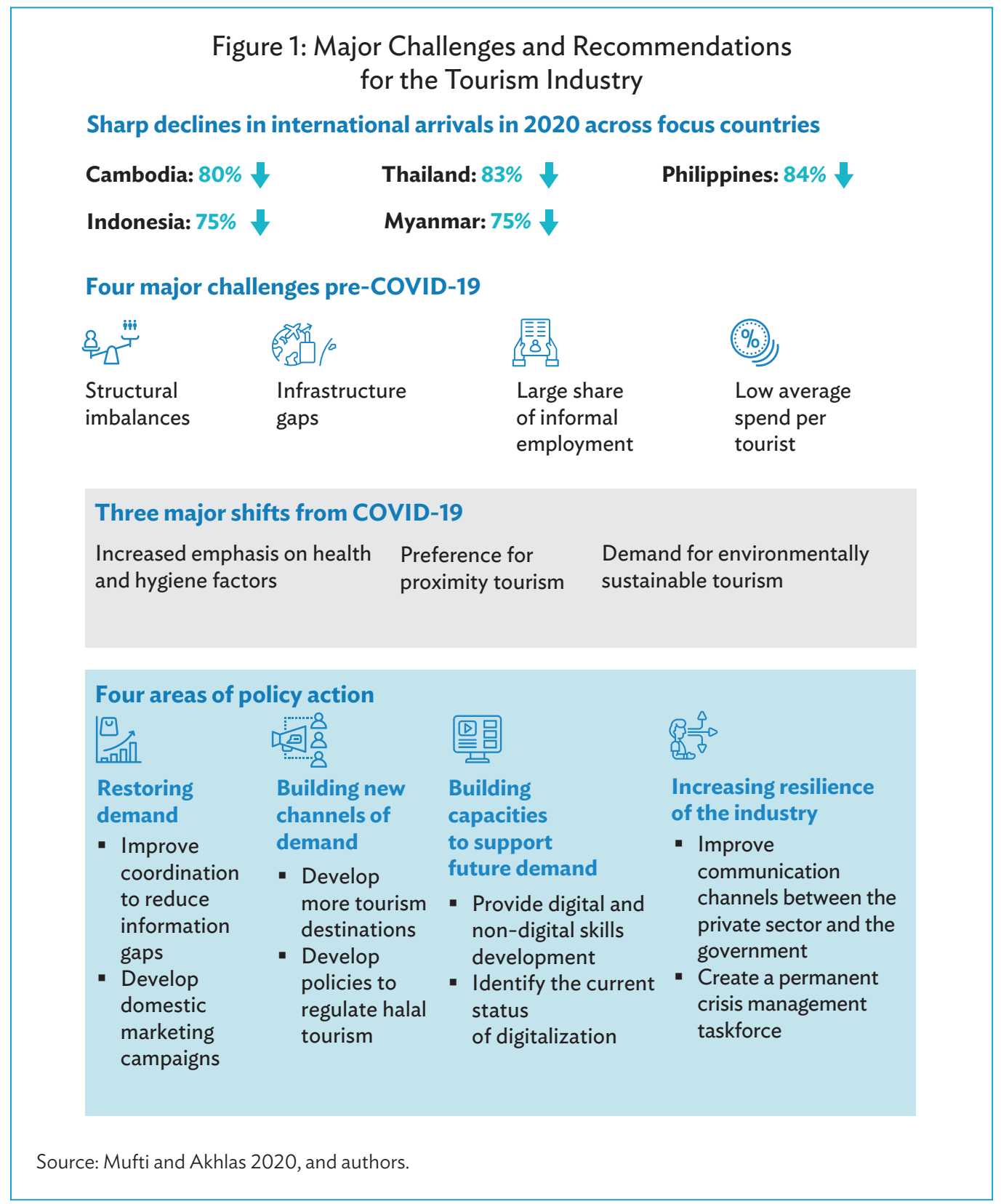

Infrastructure gaps. Underdeveloped utility, transport, and logistics infrastructure have hindered the development of the agroprocessing industry, especially in rural areas.

Lack of access to key enablers. Many of the challenges limiting access of agro-processing industry operators to enablers, such as financing, new technologies, skilled labor, stable and high-value markets, and nurturing business environments, are due to their size as the majority of firms are micro, small, and medium-sized enterprises.

Lack of environmental sustainability and shifting consumer purchasing behaviors. The agro-processing industry contributes to food loss and waste generation across the production value chain. This includes waste during processing, packaging, and distribution to food markets, and spoilage at wholesale and retail markets. There has also been a shift in consumer preference toward environmentally sustainable products, putting some regional producers at a disadvantage due to their inability to provide this (Devenyms 2020).

\section{Impact of COVID-19 on Agro-Processing}

As countries around the world imposed travel restrictions, closed borders, and curtailed business activities and transportation networks, fluctuations in production factors like labor and raw materials followed. Labor shortages at factories, warehouses, 
and logistics hubs caused disruptions in supply chains and some countries imposed restrictions on food product exports and imports to prioritize domestic needs. Fortunately, some of these measures were only short-term and were removed after a few months. While agriculture has been less affected by the COVID-19 pandemic than other sectors, the region's governments must now support efforts to move toward higher value-added activities like agro-processing (ITC 2021).

\section{Post-COVID-19 Policy Response}

Figure 2 presents policy responses to the impact of the COVID-19 pandemic on the agro-processing sector in Southeast Asia, focusing on the following:

Enhancing the efficiency and transparency of supply chains. Harmonizing standards for food products, where possible, would

\section{Figure 2: Major Challenges and Recommendations for the Agro-Processing Industry}

Five major challenges pre-COVID-19

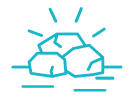

Inconsistent supply of raw materials and technological adoption

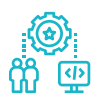

Infrastructure gaps such as financing, technologies, and skilled labor

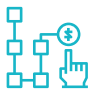

Lack of

environmental sustainability and shifting consumer purchasing behaviors

Three major shifts from COVID-19

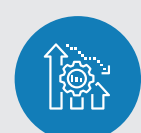

Shifts in demand for food and beverage products

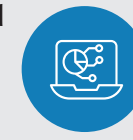

Breakdown in the supply of production inputs

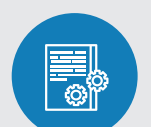

Increased food protectionism policies

\begin{tabular}{|c|c|c|c|}
\hline \multicolumn{4}{|c|}{ Four areas of policy action } \\
\hline 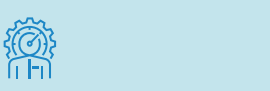 & मीं? & 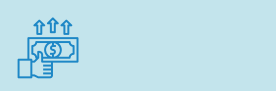 & 吸数 \\
\hline $\begin{array}{l}\text { Enhancing the } \\
\text { efficiency and } \\
\text { transparency of } \\
\text { supply chains } \\
\text { - Invest in reliable } \\
\text { data management } \\
\text { systems } \\
\text { - Harmonize } \\
\text { standards for } \\
\text { food products }\end{array}$ & $\begin{array}{l}\text { Strengthening } \\
\text { the industry's } \\
\text { added value } \\
\text { - Expand food } \\
\text { product range } \\
\text { - Attract } \\
\text { investments } \\
\text { and companies }\end{array}$ & $\begin{array}{l}\text { Pursuing steps } \\
\text { to raise } \\
\text { productivity rates } \\
\text { - Focus on } \\
\text { research and } \\
\text { enabling policies } \\
\text { to ensure a more } \\
\text { consistent supply } \\
\text { of raw materials }\end{array}$ & $\begin{array}{l}\text { Building industry } \\
\text { resilience } \\
\text { - Streamline } \\
\text { regulatory functions } \\
\text { - Strengthen the local } \\
\text { agro-processing } \\
\text { ecosystem } \\
\text { - Pursue food-related } \\
\text { circularity policies }\end{array}$ \\
\hline
\end{tabular}


help agro-processing industries avoid delays and unnecessary compliance costs. Improving the cross-border customs processes of food products and production inputs would reduce food loss related to handling and ease access to essential raw materials such as pesticides. The OECD reports that digital technologies, with the appropriate information and communications technology infrastructure, could help reduce export times by 44\% in Asia and the Pacific (Jouanjean 2019).

\section{Adding value of the industry and expanding sales}

channels. As incomes increase and consumers become more informed, demand has increased for healthier food options, including organic, "free-from" (e.g., gluten-free), functional, and reformulated. Factors to expand the food product range include operational enhancements like growing organic produce; sales strategies such as targeting high-end supermarkets to expatriates; and technical expertise such as training workers in reformulated food processing. Since the outbreak, 23\% of consumers in Southeast Asia have started using e-commerce platforms to purchase products for the first time (Yendamuri, Keswakaroon, and Lim 2020). Countries could help businesses expand their sales channels, especially digital ones, and adding value in agro-processing by improving digital connectivity (e.g., expanding internet coverage) and helping companies access digital platforms.

Improving productivity, quality, and safety. There is room to enhance productivity rates through (i) focusing on research and enabling policies to ensure a more consistent supply of raw materials of high quality and safety; (ii) promoting the adoption of processing equipment; and (iii) facilitating digital transformation in the agro-processing industry. The food and beverage manufacturing industry could be transformed through Industry 4.0, including the use of big data and the Internet of Things to enhance demand forecasting and production planning to improve customer service levels and boost profit margins (McKinsey Global Institute 2014). Productivity can rise $50 \%$ by adopting the relevant technologies in the agro-processing industry in Southeast Asia (McKinsey \& Company 2018).

Building industry resilience. The COVID-19 crisis has demonstrated that the agro-processing industry in Southeast Asia is particularly vulnerable to shocks. Some potential policies to enhance resilience include (i) streamlining regulatory functions (e.g., oversight from ministries including agriculture, health, industry, commerce and trade); (ii) strengthening the local agro-processing ecosystem by placing more emphasis on diversification, shorter supply chains, local alternative supplies, and local markets; (iii) promoting partnerships between agroprocessing stakeholders in the private sector, government, and with other countries in the region; and (iv) pursuing foodrelated circularity policies to tackle post-harvest and supply chain waste.

\section{GARMENTS}

Many Southeast Asian countries are competitive in the laborintensive textile, apparel, and footwear manufacturing industries due to their relatively low labor costs, strategic location, preferential market access, and supportive government policies. At the same time, some countries continue to focus on high volumes of low value-added products, relying on cheap labor as their primary competitive advantage (Huynh 2015). Southeast Asian garments manufacturers are vulnerable to supply chain disruptions due to a heavy reliance on a few key raw materials suppliers; insufficient reliability, timing, and scale of local input production (deepening their dependence on foreign suppliers); and irregular electricity supplies. While rising labor costs are adding economic pressure in some countries, low labor productivity also needs to be addressed (Andersson, Machiels, and Bodwell 2019).

\section{Impact of COVID-19 on the Garments Industry}

The garments industry in Southeast Asia has been severely affected by COVID-19. The cancellation of orders and production restrictions have forced many Southeast Asian companies to cease operations and lay off employees. The pre-pandemic challenges facing the industry have been exacerbated, resulting in greater fluctuations and shortages of production factors such as raw materials that impact different parts of the value chain. Workplace closures in other countries have prevented imported inputs from reaching garment production in time and disrupted garment manufacturing. Furthermore, studies suggest that the COVID-19 pandemic may lead to greater demand for sustainable fashion products as consumers shift from purchasing new garments to reusing them (Richetti and Palma 2020).

The COVID-19 crisis has also highlighted the lack of support services for vulnerable workers in the industry, exacerbating inequalities. In the short term, lack of access to necessities, unequal domestic responsibilities, gender-based discrimination in hiring, and increased risk of gender-based violence could make women workers in the industry more vulnerable. There are also longer-term consequences, as limited access to social assistance, unregulated worker conditions, and reduced access to health services could diminish the economic and social empowerment of women (ILO 2020). The pandemic may also severely impact children, as well, with economic pressures and limited safety nets pushing many children into child labor (ILO and UNICEF 2020).

\section{Post-COVID-19 Policy Response}

Governments have implemented short-term measures such as wage support to mitigate impacts of the pandemic on the industry. In the longer term, a range of policy responses could address challenges and support the industry in achieving higher and more 
sustainable growth. The policy responses suggested in Figure 3 could help in four ways.

Improve competitiveness. Enhancing competitiveness through productivity gains is important to maintaining the industry's growth potential. Specific areas to emphasize include (i) reviewing policies that restrict growth such as high raw material tariffs and cumbersome export permit procedures that contribute to high production costs; (ii) upgrading vocational curricula and increasing access to training, particularly in rural regions; and (iii) promoting the adoption of digital technologies ranging from smart factories to additive manufacturing to enable mass customization of products.

Expand markets. Currently, the region's exports focus on specific markets such as the European Union and the United States. There are risks that the trade preferences facilitating such exports may eventually be removed through violation or graduation. The industry also needs to pursue product differentiation and produce higher value-added garments to remain attractive.

\section{Figure 3: Major Challenges and Recommendations for the Garments Industry}

Eight major challenges pre-COVID-19

$\begin{array}{ll}\begin{array}{l}\text { Focus on low } \\ \text { value-added products }\end{array} & \begin{array}{l}\text { Concentrated supply } \\ \text { base of raw materials }\end{array}\end{array}$

Three major shifts from COVID-19

Supply chain
disruptions

Four areas of policy action

泪:

Improving competitiveness

- Review policies that are restricting growth

- Promote the adoption of digital technologies in the industry

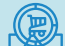

?

Expanding markets

- Develop more end markets

- Leverage cultural-related garments

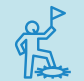

Raising industry resilience

- Promote domestic production of related agricultural products

- Guarantee demand for sustainable manufacturers

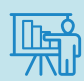

Pursuing more flexible production and business models

- Drive research and development 
With consumers moving away from mass-produced clothes, governments could incentivize companies to explore more sophisticated product offerings (McKinsey \& Company 2019).

Raise industry resilience. Improving productivity and adopting better production technologies can strengthen the sector's resilience to future demand shocks. An ADB study found that applying new technologies to the industry could increase labor productivity by an average of $22 \%$ in the next 5 years. (ADB 2021). There should be more emphasis on shorter supply chains, local alternative supplies, and local markets. Governments could also provide funding for machinery, upskilling workers, and attracting foreign investors to facilitate more value-added production techniques. Finally, circular economy adoption has been mooted as a sustainable way to pursue recovery across industries, including garments manufacturing, where there has been an increased focus on its inefficient resource use, pollutive impacts, and overproduction (Centre for the Promotion of Imports 2020 and Wijayasundara 2020).

Pursue more flexible production and business models. To increase the flexibility of firms to respond to future shocks, garment factories may need to be able to switch across production types to meet changing consumer demand. Governments can spearhead research and development (R\&D) into new technologies and their application in such factories, which would also require workers with multiple, transferable skills.

\section{ELECTRONICS}

Electronics manufacturing is an important sector for the region. The diversity of products produced range from capitalintensive products such as hard drives to more labor-intensive products such as electrical components. While most electronics manufactured are destined for exports, some products like consumer electronics are kept in domestic markets. Structural challenges facing the region's electronics sector must first be addressed to facilitate the sector's growth in the post-COVID-19 world. These constraints are summarized below.

Lack of diversification across the electronics supply chain. The electronics manufacturing industry in Southeast Asia generally has inadequate industrial systems and lacks the complete upstream and downstream portions of the value chains. Upstream, electronics manufacturers continue to rely heavily on a global industrial chain based in the People's Republic of China (PRC), particularly for raw materials and intermediate products. Downstream, strong customer concentration in a few export markets also poses risks to the industry (Yu 2020).

Focus on low value-added products and processes. Many countries have a relatively stronger focus on the assembly and testing stages of the industry value chain rather than upstream stages that generate higher economic value such as R\&D and product design. Production in the region also tends to focus on making simpler electronics like hard disk drives than on hightech activities that generate greater economic contributions, like semiconductor fabrication. The sector's predominantly low-skilled labor force is one reason for the lack of capacity to transition beyond assembly operations.

\section{Disruptive technologies and the potential impact on the} labor force. The growing interconnectedness of global supply chains, the need for more complex designs and shorter delivery times, and a rising focus on the reliability of production systems require electronics manufacturing companies in the region to adapt to new technologies, including the Internet of Things, artificial intelligence, and machine-learning technologies, industry robotics (allowing for the automation of repetitive tasks such as components assembly), and additive manufacturing (Litzenberger 2018, McKinsey \& Company 2018, and McKinsey Global Institute 2014).

Rapid changes in electronics technology and consumption trends. Technological trends necessitate manufacturers to constantly upgrade and adapt their manufacturing inputs and processes, which can be cost-prohibitive in the long term. In addition, the diversification of manufacturing out of traditional locations like the PRC due to economic and geopolitical considerations presents countries in the region with opportunities to increase their electronics manufacturing footprint or risk being left behind.

\section{Impact of COVID-19 on the Electronics Industry}

The COVID-19 pandemic has accelerated a global digital transformation while at the same time harming the industry. Many regional electronics manufacturers face delays in production due to supply chain interruptions, resulting in the failure to meet the rising demand for some consumer electronics during the pandemic. Interruptions in manufacturing and shipping trigger a domino effect on transportation, sales, prototyping, and the launch of new products across the industry (Leopold 2020). As new lifestyle paradigms birthed by the pandemic could alter electronics demand, the challenge will be to understand and keep pace with these structural shifts.

\section{Post-COVID-19 Policy Response}

The COVID-19 pandemic has forced consumers to adopt new ways of working and living that could fundamentally change the demand for electronics components manufactured in Southeast Asia. To address the challenges identified and improve the competitiveness of the electronics industry in a post-COVID-19 world, as shown in Figure 4, policies should support the following: 


\section{Figure 4: Major Challenges and Recommendations for the Electronics Industry \\ Four major challenges pre-COVID-19

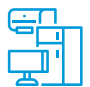 \\ Lack of diversification across the electronics supply chain

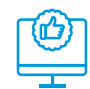 \\ Focus on low value-added products and processes

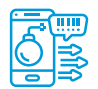 \\ Disruptive technologies

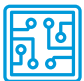 \\ Rapid changes in electronics technology and consumption trends}

\section{Two major shifts from COVID-19

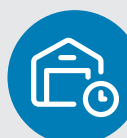 \\ Production delays \\ Acceleration in changing landscape of consumer demand}

\section{Two areas of policy action}

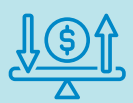

Upgrading special economic zones

- Adopt zone specialization to maximize industry linkages

- Develop supportive policies specific to the electronics industry
(8)

Develop human capital

- Create dedicated strategies and government agencies

- Incentivize local companies to engage in research and development
Upgrade special economic zones. SEZs are geographically delimited areas within which governments facilitate industrial activity through fiscal and regulatory incentives and infrastructure support (UNCTAD 2019). SEZs cluster firms to reap economies of scale, while facilitating potential spillovers in technology, labor skills, and market opportunities. Developing SEZs for the electronics industry can maximize industry linkages, leading to more collaboration and pooling of resources while promoting competition. Creating industry-specific policies such as promoting electronics export in free trade agreements would also benefit the region's manufacturers. Finally, increased collaboration between government and industry, and local players and foreign investors, can facilitate the transition toward high-value activities within the electronics supply chain.
Develop human capital. Southeast Asian countries need to actively develop human capital to attract foreign direct investment, remain competitive, and transit to manufacturing electronics with high added value. Governments could dedicate training resources to industry-specific programs, partner with other stakeholders, and create dedicated government agencies. Governments also need to prioritize upskilling and reskilling of workers in the electronics industry, for instance through partnering with private sector stakeholders and learning institutions. Likewise, promoting and investing in science, technology, engineering, and math education to ensure a supply of high-skilled workers can contribute to an enabling environment for innovation. The application of new technologies to the electronics industry could increase labor productivity by about $40 \%$ in the next 5 years (ADB 
2021). Southeast Asian governments can also emphasize the need for mutually agreeable clauses between international and domestic firms that facilitate knowledge transfer and consider providing incentives for local companies to engage in R\&D. Emerging manufacturing areas like biotechnology might provide case studies for the electronics industry in the region.

\section{DIGITAL TRADE}

Digital trade is a relatively new and emerging sector. While the contributions to GDP of digital products (software); digitally enabled services (business process outsourcing, online advertising, export of data processing services); and indirect digital services are not yet captured well in national statistics across Southeast Asia, their importance is likely to grow tremendously as more activities shift online in the post-COVID-19 world. Much of the region's digital trade is currently concentrated in information technology and business process outsourcing (IT-BPO). Software application (app) development has also been picking up in some Southeast Asian countries. To harness the growth potential of the region's digital trade sector, the following key challenges are vital to address.

Automation. While digital technologies have spurred the growth of the IT-BPO segment of the digital trade sector and could further increase the productivity of workers in Southeast Asian countries (for example, by providing real-time insights into customers), the increasing sophistication of artificial intelligence technologies could also remove the need for human involvement in many IT-BPO functions.

Connectivity. Mobile and broadband connectivity is critical, but there are gaps in both access and speed across the region. This is a key bottleneck for inclusive growth as it stands in the way of market access for both enterprises and consumers. Sub-standard or unaffordable digital connectivity also negatively impacts on the future growth potential of digital trade as it holds back education and skill development.

SME development. Many small and medium-sized enterprises (SMEs) lack the resources to research international sales opportunities, to build a global business network, and to market their products overseas. Digital technologies can help, but many SMEs lack understanding of available digital solutions, available software or business platforms, and related trade opportunities. Some may consider the (further) digitalization of their business model and IT infrastructure as too risky, disruptive, or costly.

Tax base erosion. Policy makers fear that digital trade makes it easier for companies to shift profits to low-tax jurisdictions to avoid paying taxes. As government officials have increasingly acknowledged, an international approach to tackling base erosion and profit shifting is needed.
Regulatory framework. Regulation covering the digital domain is being introduced across the region to address concerns ranging from data privacy to economic competitiveness. Businesses generally welcome a clear regulatory environment that provides a level playing field, adheres to international standards, and is ideally coordinated regionally. However, some regulations risk undermining digital trade growth. For example, far-reaching data localization requirements have been associated with investment decreases of up to $4 \%$ (Bauer et al. 2014).

\section{Impact of COVID-19 on Digital Trade and Policy Response}

The digital trade sector is home to economic activities and jobs that are more amenable to remote work and have proven more resilient to the COVID-19 pandemic than in other sectors. An enabling environment is needed to grow the sector in Southeast Asia and secure the potential benefits from expanded digital exports. Figure 5 presents key recommendations to support an enabling environment for digital trade, which include the following:

Develop an IT-BPO road map. The development of the IT-BPO industry would benefit from a clear national road map that reflects an understanding of emerging technology opportunities, skills requirements, and detailed policies.

Enhance connectivity. The reasons for the underdevelopment of broadband networks in some Southeast Asian countries include the lack of access to enabling infrastructure (such as an electrical grid) or limited investments into network expansion due to commercial unviability (e.g., difficult terrain, low population density in rural areas, or remote locations). Therefore, greater investments will be needed to expand the enabling network infrastructure and incentivize investment. Innovative business models to increase the affordability of mobile and fixed broadband connectivity are also needed.

Support skills development. A range of initiatives is needed to support digital skills development. Greater industry involvement in curriculum development can help ensure that key skills such as English language fluency, critical thinking, and complex problemsolving are covered. This needs to be accompanied by support and financial incentives for employers to ensure more and higher quality training in the workplace (ADB 2021).

Enable SMEs to go digital. Focused government programs to support the digitalization of SMEs could improve the productivity of their workforce (ADB 2021), enhance business processes and customer experiences, boost innovation, and open up new markets. SMEs are also customers of business-to-business digital services which are often provided by start-ups or other SMEs whose growth will be boosted by such government schemes. Helping traditional sectors transition to the digital age will not only enhance their competitiveness but will also boost the emergence of an innovative digital economy. 


\section{Figure 5: Major Challenges and Recommendations for Digital Trade}

Five major challenges pre-COVID-19

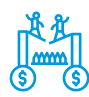

RISK OF AUTOMATION

89\% of Filipino BPO workers are at high risk of automation $^{\mathrm{a}}$

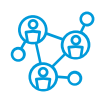

LIMITED

CONNECTIVITY

Fixed broadband

speeds in Indonesia and the Philippines are 6.7 and $6 \mathrm{Mbps}$, respectively,

less than

one-tenth of

the speeds in

Singapore ${ }^{\mathrm{b}}$

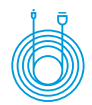

LOW LEVEL

OF SME

DIGITALIZATION

In Thailand, just

$1.7 \%$ of businesses

received internet

orders, with the

lowest rates

among SMEs ${ }^{c}$

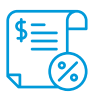

TAX BASE

EROSION

Taxation of digital

payments

could slow

down

growth

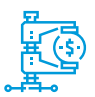

RISK OF

RESTRICTIVE

DIGITAL

REGULATION

Macroeconomic

costs of forced

data localization

range between

$0.7 \%$ and

$1.1 \%$ of GDP

Five areas of policy action

四

它

Develop an

IT-BPO

road map

- Introduce

industry

transformation

maps (ITMs)
8 壁

Enhance connectivity

- Leverage nonbroadband infrastructure projects such as road construction

\section{शूर}

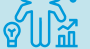

Support skills

development

- Provide

financial

incentives
జణ. \lfloor

Enable SMEs to go digital

- Design tool kits for SMEs to assess their digital readiness

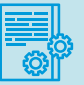

Rethink digital regulation

- Raise de minimis thresholds

- Enact data localization reforms

GDP = gross domestic product, IT-BPO = information technology and business process outsourcing,

$\mathrm{SME}=$ small and medium-sized enterprise.

a ACT/EMP and International Labour Organization. 2017. ASEAN in Transformation-How Technology is Changing Jobs and Enterprises-The Philippines Country Brief. https://www.ilo.org/wcmsp5/groups/public/---ed_dialogue/--act_emp/documents/publication/wcms_579667.pdf.

b OECD. 2019. Southeast Asia Going Digital: Connecting SMEs. Paris. https://www.oecd.org/going-digital/southeastasia-connecting-SMEs.pdf.

c UNCTAD. UNCTADStat. http://unctadstat.unctad.org (accessed on 16 March 2021).

d Bauer et al. 2014.

Source: Authors.

Rethink digital regulation. Cross-border trade would be greatly enhanced by reducing the need for local registration (which can be cost-prohibitive for SMEs) removing disclosure requirements for key intellectual property, and minimizing unnecessary procedures and duties. For instance, raising de minimis thresholds on custom duties for digital products is important, particularly for SMEs.

Adopting bilateral (or multilateral) approaches to data flows would also enhance cross-border trade. A useful starting point would be to adopt the APEC Privacy Framework and join its Cross Border Privacy Rules System as well as adopt international standards (such as ISO27018) that specify controls to protect personal data (Hinrich Foundation 2019). This could be supported by encouraging interoperability between digital frameworks, particularly on payment gateways, to avoid the costs of companies having to customize their approaches to every single market. Finally, within ASEAN, it will be important for countries to progress on the data management initiative under the Master Plan on ASEAN Connectivity 2025 (MPAC 2025), which aims to improve transparency and accountability on data regulation requirements in ASEAN, and identify areas to enhance performance and coordination (ASEAN Secretariat 2016). 


\section{CONCLUSION}

As countries look to get their economies back on track, they need to support sectors that have been badly impacted by the pandemic, while also investing in new growth areas. Enhancing the investment climate and strengthening infrastructure will contribute to achieving these goals. With digital transformation becoming more important, investing in digital skills will be necessary. Many of the challenges ahead will require governments and businesses to work closely together.

\section{REFERENCES}

Andersson, S., A. Machiels, and C. Bodwell. 2019. Securing the Competitiveness of Asia's Garment Sector: A Framework for Enhancing Factory-Level Productivity. ILO Asia- Pacific Working Paper Series. Bangkok: International Labour Organization (ILO).

Asian Development Bank (ADB). 2021. Reaping the Benefits of Industry 4.0 through Skills Development in High-Growth Industries in Southeast Asia: Insight from Cambodia, Indonesia, the Philippines, and Viet Nam. Manila.

ASEAN Secretariat. 2016. Master Plan on ASEAN Connectivity 2025. Jakarta. http://asean.org/storage/2016/09/Master-Plan-onASEAN-Connectivity-20251.pdf.

—. Statistics Division. 2021. ASEAN Visitor Arrivals Dashboard. Jakarta. https://data.aseanstats.org/dashboard/ tourism (accessed 11 March 2021).

Bauer et al. 2014. The Costs of Data Localisation: A Friendly Fire on Economic Recovery. ECIPE Occasional Paper. No. 3. Brussels: European Centre for International Political Economy.

Centre for the Promotion of Imports (CBI), Netherlands Enterprise Agency, Netherlands Ministry of Foreign Affairs. 2020. How to Respond to COVID-19 in the Apparel Sector. The Hague. https://www.cbi.eu/market-information/apparel/how-respondcovid-19-apparel-sector\#change-from-mass-production-tomade-to-measure.

Deloitte. 2019. Converge: Cultivating Southeast Asia for the Future of Food. Singapore.

Devenyms, J. 2020. Consumers Still Care About Sustainability Amid Pandemic, Report Finds. Food Dive. 24 April.

https://www.fooddive.com/news/consumers-still-care-aboutsustainability-amid-pandemic-report-finds/576682/.

Hinrich Foundation and AlphaBeta. 2019. The Digital Komodo Dragon: How Indonesia can capture the digital trade opportunity at home and abroad. Jakarta. https://alphabeta.com/wp-content/ uploads/2019/02/digitrade_indo_eng_1-pg-view.pdf.
Huynh, P. 2015. Employment, Wages and Working Conditions in Asia's Garment Sector: Finding new drivers of competitiveness. ILO Asia-Pacific Working Paper Series. Bangkok: ILO.

ILO. 2020. Gendered Impacts of COVID-19 on the Garment Sector. Geneva.

ILO and United Nations Children's Fund (UNICEF). 2020. COVID-19 and Child Labour: A Time of Crisis, A Time to Act. New York.

International Trade Centre (ITC). COVID-19 Temporary Trade Measures (Database). https://www.macmap.org/covid19 (accessed 6 March 2021).

Jouanjean, M. 2019. Digital Opportunities for Trade in the Agriculture and Food Sectors. OECD Food, Agriculture and Fisheries Papers. No. 122. Paris: Organisation for Economic Co-operation and Development (OECD) Publishing.

Leopold, G. 2020. Pandemic Delays Electronic Product Launches. EE Times. 20 May. https://www.eetimes.com/ pandemic-delays-electronic-product-launches/.

Litzenberger, G. 2018. Automation Boom in Electrical / Electronics Industry Drives 30\% Increase in Sales of Industrial Robots. International Federation of Robotics. 7 November. https://ifr.org/post/automation-boom-in-electrical-electronicsindustry-drives-30-increase-in-sa.

McKinsey \& Company. 2018. Industry 4.0: Reinvigorating ASEAN Manufacturing for the Future. https://www.mckinsey.com/ business-functions/operations/our-insights/industry-4-0reinvigorating-asean-manufacturing-for-the-future

2019. The State of Fashion 2019. https://www.mckinsey. $\mathrm{com} / \sim$ media/McKinsey/Industries/Retail/Our\%20Insights/ The $\% 20$ influence $\% 20$ of $\% 20$ woke $\% 20$ consumers $\% 20$ on $\% 20$ fashion/The-State-of-Fashion-2019.ashx.

McKinsey Global Institute. 2014. Southeast Asia at the Crossroads: Three paths to prosperity. https://www.mckinsey. $\mathrm{com} /$ featured-insights/asia-pacific/three-paths-to-sustainedeconomic-growth-in-southeast-asia.

Mufti, R. R. and A. W. Akhlas. 2020. Tourism Recovery Still a Long Way Off Despite Slight Increase in Visitors in May: Experts. The Jakarta Post. 2 July.

OECD. 2020. Rebuilding Tourism for the Future: COVID-19 Policy Response and Recovery. OECD Policy Responses to Coronavirus (COVID-19). Paris: OECD Publishing. 
Ricchetti M. and R. D. Palma. 2020. Will COVID-19 Accelerate the Transition to a Sustainable Fashion Industry? United Nations Industrial Development Organization. 9 October.

https://www.unido.org/stories/will-covid-19-accelerate-transitionsustainable-fashion-industry.

Romagosa, F. 2020. The COVID-19 Crisis: Opportunities for Sustainable and Proximity tourism. Tourism Geographies. 22 (3). pp. 690-694.

Soni, K. 2020. COVID-19 Could Change Travel - But Not in the Way You Think. World Economic Forum (WEF). 25 September. https://www.weforum.org/discom?bobulate $=$ G2CKD5eAVWn\%2B 9LIdBniEEOte9zSebv\%2B\%2FiyrJiHBWVRAobPq0Q5ik1pSOGRS\% 2B\%0A\%2Fcu9BrtVmhQ\%2BJDiWaCCiGaEcfw\%3D\%3D\%0A.

United Nations Conference on Trade and Development (UNCTAD). 2019. World Investment Report 2019. Special Economic Zones. New York: United Nations Publications.
Wijayasundara, M. 2020. Opportunities for a Circular Economy Post COVID-19. WEF. 22 June. https://www.weforum.org/ agenda/2020/06/opportunities-circular-economy-postcovid-19/.

Winterflood, J. 2020. Post-Pandemic, Will Bali Rethink Tourism? The Diplomat. 10 June. https://thediplomat.com/2020/06/postpandemic-will-bali-rethink-tourism/.

Yendamuri P., D. Keswakaroon, and G. Lim. 2020. How Covid-19 Is Changing Southeast Asia's Consumers. Bain \& Company. 26 June. https://www.bain.com/insights/how-covid-19-is-changing-southeastasias-consumers/.

Yu, H. 2020. Wake-Up Call for ASEAN Countries: Curb OverReliance on China and Seize Opportunities of Global Supply Chain Restructuring. ThinkChina. 26 March. https://www.thinkchina.sg/ wake-call-asean-countries-curb-over-reliance-china-and-seizeopportunities-global-supply-chain.
About the Asian Development Bank

ADB is committed to achieving a prosperous, inclusive, resilient, and sustainable Asia and the Pacific, while sustaining its efforts to eradicate extreme poverty. Established in 1966, it is owned by 68 members49 from the region. Its main instruments for helping its developing member countries are policy dialogue, loans, equity investments, guarantees, grants, and technical assistance.

ADB Briefs are based on papers or notes prepared by ADB staff and their resource persons. The series is designed to provide concise, nontechnical accounts of policy issues of topical interest, with a view to facilitating informed debate. The Department of Communications administers the series.

ADB recognizes "China" as the People's Republic of China. In this publication, “\$” refers to United States dollars.
The views expressed in this publication are those of the authors and do not necessarily reflect the views and policies of ADB or its Board of Governors or the governments they represent. ADB encourages printing or copying information exclusively for personal and noncommercial use with proper acknowledgment of ADB. Users are restricted from reselling, redistributing, or creating derivative works for commercial purposes without the express, written consent of ADB.

Asian Development Bank

6 ADB Avenue, Mandaluyong City

1550 Metro Manila, Philippines

Tel +63286324444

Fax +63286362444

www.adb.org/publications/series/adb-briefs 